DOI: https://doi.org/10.34069/AI/2021.47.11.23

How to Cite:

Mozol, V., Balaban, S., Kryzhanovskyi, O., Oliinyk, Y., \& Babiak, A. (2021). Interaction of the National Police with other actors in the area of criminal justice in combating criminal offences in the area of land relations. Amazonia Investiga, 10(47), 226-233. https://doi.org/10.34069/AI/2021.47.11.23

\title{
Interaction of the National Police with other actors in the area of criminal justice in combating criminal offences in the area of land relations
}

\section{Взаємодія Національної поліції з іншими суб’сктами щодо протидії кримінальним правопорушенням у сфері земельних відносин}

Received: October 30, 2021

Abstract

The aim of the article is the comprehensive analysis of the interaction of the National Police with other actors in the detection and investigation of criminal offenses in the area of land relations. Methodology. The specifics of the purpose and objectives of the study necessitated the use of the following methods: dialectical, comparative and legal, dogmatic, system and structural, modeling, sociological, statistical methods, etc. Results of the research. The article provides a comprehensive analysis of the interaction of the National Police with other actors in combating criminal offenses in the area of land relations. The main tendencies of land security in Ukraine are considered and the directions of the interaction of the National Police bodies with control and audit agencies are singled out. Practical meaning. Scientific and theoretical conclusions and practical proposals aimed at improving the legal regulation of such interaction are substantiated. Value / originality.
Accepted: November 30, 2021

Written by:

Mozol Viktoriia ${ }^{98}$

https://orcid.org/0000-0003-0835-1019

Balaban Serhii ${ }^{99}$

https://orcid.org/0000-0003-1089-8128

Kryzhanovskyi Oleksii ${ }^{100}$

https://orcid.org/0000-0002-5358-9758

Oliinyk Yuriii ${ }^{101}$

https://orcid.org/0000-0002-7771-2124

Babiak Andrii ${ }^{102}$

https://orcid.org/0000-0002-2284-3864

\section{Анотація}

Метою статті є комплексний аналіз взаємодії органів Національної поліції 3 іншими суб'єктами при виявленні та розслідуванні кримінальних правопорушень у сфері земельних відносин Предметом дослідження $\epsilon$ взаємодія органів Національної поліції з іншими органами державної влади та місцевого самоврядування. Методологія. Специфіка мети та завдань дослідження зумовила необхідність використання таких методів: діалектичного, порівняльно-правового, системно-структурного, догматичного, моделюючого, соціологічного, статистичного методів тощо. Результати дослідження. У статті проведено комплексний аналіз взаємодії органів Національної поліції з іншими суб'єктами при виявленні та розслідуванні кримінальних правопорушень у сфері земельних відносин. Розглянуто основні тенденції забезпечення земельної безпеки в Україні, надано авторське визначення взаємодії Національної поліції 3 іншими суб'єктами, виокремлено напрями

\footnotetext{
${ }^{98} \mathrm{PhD}$, Senior Researcher of the Scientific Laboratory for Preventive Activities and Prevention of Corruption of the Educational and Scientific Institute №3 of the National Academy of Internal Affairs, Ukraine.

${ }^{99} \mathrm{PhD}$ in Law, Associate Professor of Criminal Law Department of Dnipropetrovs'k State University of Internal Affairs, Ukraine.

${ }^{100} \mathrm{PhD}$ in Law, Associate Professor of the Department of Criminal Law and Criminology of Donetsk State University of Internal Affairs, Ukraine.

${ }^{101} \mathrm{PhD}$ in Law, Instructor of the Department of Firearm Training of the National Academy of Internal Affairs, Ukraine.

${ }^{102}$ Candidate of Legal Sciences, Associate Professor, Head of the Department of Operative and Search activity of Lviv State University of Internal Affairs, Ukraine.
} 


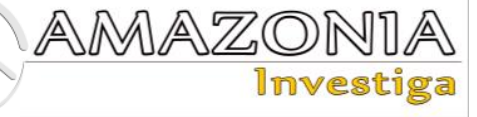

The authors' definition of the concept of interaction of the National Police with other actors in the investigation of criminal offenses in the area of land relations is provided.

Key words: interaction, investigation, land relations, prevention, National Police. взаємодії 3 контрольними та ревізійними органами. Практичне значення. Обгрунтовано науково-теоретичні висновки та практичні пропозиції, спрямовані на вдосконалення нормативно-правового регулювання такої взаємодії. Цінність / оригінальність. Надано авторське визначення взаємодії слідчих 3 оперативними підрозділами та іншими суб'єктами у розслідуванні кримінальних правопорушень у сфері земельних відносин.

Ключові слова: взаємодія, Національна поліція, земельні відносини, запобігання, розслідування.

Statistical data show that in recent years Ukraine has significantly increased the number of registered criminal offenses in the area of land relations; in particular, in 2018, 2,722 such criminal proceedings were recorded, in 2019 2020, the number increased to 3,613 and 4194 proceedings, respectively. Despite 18594 inspections of compliance with land legislation in 2020 were conducted, 1932 petitions and 5331 instructions were issued, 4542 protocols and 4149 resolutions on imposition of fines amounting to UAH 3.3 million were drawn up, and 1721 materials were submitted to the prosecutor's office, one of the main tasks minimizing the commission of criminal offences - is not sufficiently implemented. According to the analysis of law enforcement practice, the investigation is not always effective and efficient, resulting in the closure of criminal proceedings and the imposition of acquittals (13.7 per cent found that, contrary to the established procedure, the offence had not been proved to have been committed; 12.2 per cent includes circumstances, the resolution of which requires authorization in the area of civil or administrative proceedings). The poor performance of pre-trial investigation bodies leads to criminal offenses in this area become systemic and continue to create serious obstacles to the development of potentially the most powerful sector of Ukraine's economy, threatening national security (Office of the Prosecutor's General of Ukraine, 2021; Research Institute of the Ministry of Internal Affairs of Ukraine, 2020).

Scientific research on this issue is extremely relevant today and has important theoretical and practical significance, since the objective increase in the number of criminal proceedings in the above category is in contrast with the decrease in convictions suggests the need to improve the collection of evidence, research, 
verification and use. Full implementation of land protection objectives in Ukraine becomes possible only with the strengthening of effective law enforcement activities aimed at preventing, timely detection, cessation and investigation of such criminal offenses.

\section{Methodology}

During the preparation of the article the set of general scientific and special methods based on the theory of knowledge of legal phenomena aimed at obtaining complex reliable results is used. The specifics of the purpose and objectives of the study necessitated the use of the following methods: dialectical, comparative and legal, dogmatic, system and structural, modeling, sociological, statistical methods, etc.

Dialectical method is applied to identify the actors of interaction, their classification and procedural powers aimed at achieving the goal of pre-trial investigation.

Comparative and legal method provides an opportunity to investigate the powers of different actors in combating criminal offences in the area of land relations.

On the basis of dogmatic method the interpretation of the legal categories "interaction", "public security" and "public order" is carried out.

System and structural method helps to identify the features of procedural and non-procedural forms of interaction of investigator and other actors in combating criminal offences in the area of land relations, to determine their powers and main areas of their implementation during proceedings.

Modeling and legal method is useful during the substantiation of the proposition to improve the interaction in the investigation of criminal offenses in the area of land relations.

With the help of sociological and statistical methods the results of the pre-trial investigation by the National Police of Ukraine and the General Prosecutor's Office of Ukraine are studied and summarized.

\section{Literature Review}

Thus, Topchii (2015) investigated theoretical and practical principles of interaction of pre-trial investigation bodies with operational units in the detection and investigation of crimes.
Feshchenko (2007) studied the problems of interaction of internal affairs bodies with the state tax service during law enforcement. Onisiev (2010) identified the features of interaction between law enforcement agencies, as well as with financial, regulatory and public organizations both on national and international levels. Patyk (2010) drew attention to the peculiarities of the interaction of investigative and operational search units in the detection and investigation of property crimes. This scientist provided a number of author's definitions, distinguished between the concepts of "interaction" and "coordination", described the forms of interaction in the investigation of property crimes, identified the areas for optimization and divided them into two groups: legal and organizational ones. Yefimenko (2014) considered the interaction of investigative and operational units in using secret information, developed theoretical provisions that reveal its concept, meaning, features and conditions of effectiveness and formulated a number of proposals to improve this activity.

The representatives of the Community Relations Service of the U.S. Department of Justice (1993) state that police-community cooperation helps considerably in combating and prevention of criminal offences. If there is confidence in governmental institutions and agencies, especially law enforcement, important information is more likely to be volunteered to authorities, suspicious and unusual activity will be reported, and investigations can proceed.

Johnson (1972) stresses the importance of police officers' cooperation with the population, who can provide them with the necessary information on the preparing encroachments or the offences, which have already been committed.

Radburn et al. (2020) stresses the importance of police-community interaction using 22 semistructured interviews conducted with officers in various roles and teams within a large metropolitan police force in England. Interviewees described complex internalised theories of social relations, differentially positioning themselves in relation to other colleagues and multiple 'publics' often depicted along socioeconomic and geographical lines.

\section{Results and Discussion}

The Law of Ukraine "On the National Police" (Law of Ukraine No. 580-VIII, 2015) is the main legislative act regulating the process of interaction between the police and other state 


\section{AMAZONIA
Investiga}

bodies. Article 5 of the abovementioned Law states that the police interact with law enforcement and other public authorities, as well as with local governments in accordance with this Law and other regulations.

Interaction is a process of joint activity of two or more actors that influence each other, which changes the qualitative characteristics of the activity of each of them and binds them together to achieve a common goal. According to Batrachenko (2017, pp. 103 - 104), interaction of the National Police with other actors in the area of public safety and order is a type of legal relationship to which different levels of the police force and law enforcement agencies, other public authorities and local governments, individuals and legal entities, their associations are subjected in order to increase the effectiveness of the National Police in ensuring public safety and order by organizing and planning joint activities in this area, combining information, technical, human and other resources for their joint use.

At the same time, the Law of Ukraine "On the National Police" uses the terms "public security" and "public order", without disclosing the content of these concepts.

The Defining Dictionary (Busel 2001) includes the following definitions of these terms:

1) "public" is something: 1) which takes place in the presence of the public, people;

2) which is intended for general attendance, use.

3) "security" is interpreted as is understood to be a state of safety when there is no threat to anyone.

4) "order" is a State, social system, the structure.

Based on the generalization of practical experience, as well as the views containing in scientific publications, we have identified the basic requirements for the instructions and follow-up on their implementation. This activity should be carried out in a certain sequence and regulated accordingly:

1. If a pre-trial investigation team is established, the investigator (prosecutor) shall issue written instructions to specific employees of the operational unit included in its composition (Order of the Ministry of Internal Affairs of Ukraine No. 575, 2017). The investigator, exercising the leadership of the investigative task force, determines the order of its work, ensures the coordinated activities of all its members, aimed at identifying, recording and removing traces of criminal offenses, the formation of the evidence base;

2. Using more information than it is presented in materials in criminal proceedings, and aimed at solving broader tasks than those solved in a particular criminal proceeding, i.e., all forms of counteraction outside the legal procedural framework aimed at establishing typical causes and conditions of criminal offenses to develop precautionary measures, generalization of the practice of responding to submissions. Investigator (prosecutor) is not allowed to provide operational unit (employee of the operational unit - a member of the investigative task force) with unspecified instructions and without a deadline for their implementation (Order of the Ministry of Internal Affairs of Ukraine No. 575, 2017).

3. The officers of operational units have no right to carry out procedural actions to counteract criminal offenses in criminal proceedings on their own initiative or to apply to the investigating judge or prosecutor. The investigator's order to carry out procedural actions is mandatory for the operational unit. Interaction between investigators and operatives usually occurs before the information is submitted to the Unified Register of Pre-trial Investigations, in particular, during joint on-site visits and urgent on-site inspections.

4. Protocols of procedural actions carried out by the officers of operational units on behalf of the investigator have the same evidentiary value as the protocols drawn up by the investigator (Order of the Ministry of Internal Affairs of Ukraine No. 575, 2017).

When engaging with land market actors, operational units should take into account the following:

- such actors are the first line of the alarm system on the possible preparation for the commission of criminal offenses and specific criminal activity, having received information on which they must transmit it to the operational units;

- interaction should maximize the potential of both sides in solving problems, use of means and methods;

- National Police, National Agency for Corruption Prevention, National AntiCorruption Bureau of Ukraine are the main law enforcement agencies in combating 
corruption offenses committed in the area of land relations, as they have the relevant, access to certain databases, sources of information on the crime situation, assist in logistical and other support;

- when determining the forms and methods of interaction it is necessary to take into account the legal basis for the organization, competence, forms and methods of the functioning of actors, in particular both in the land market and in the real estate market;

- interaction can be short-term and long-term (with systematic, jointly planned, coordinated use of forces and means of cooperation), associated with the implementation of a specific current tasks;

- there is the need to adhere to the principles of interaction (legality; independence; delimitation of competence (the actors of interaction should not perform unusual functions).

Besides, the employees of pre-trial investigation bodies when combating such criminal offenses should effectively interact with:

1) subdivisions of central executive bodies that implement State policy in the area of land relations and in the area of supervision (control) in the agro-industrial complex and perform regulatory functions, including: a) the Ministry of Environmental Protection and Natural Resources of Ukraine; b) Ministry of Agrarian Policy and Food; c) State Inspectorate for Control over Land Use and Protection, d) State Committee of Ukraine for Water Management; d) State Audit Office; e) State Financial Monitoring Service of Ukraine; g) local governments. Procedural form of interaction with the representatives of these institutions is to involve specialists in procedural actions and forensic examinations. It should be noted that most often environmental protection officers were involved by the investigator during an inspection of the site;

2) non-governmental sector entities (notaries; registrars; appraisers and surveyors; employees of security and audit services; public organizations, mass media).

It seems necessary to consider the areas of interaction between operational units and notaries $(68 \%$ of respondents indicated the effectiveness of such interaction), which, on the one hand, have broad powers and, accordingly, opportunities to detect criminal offenses in the land market, but on the other one, it is because of these possibilities that they may participate in the commission of a criminal offence. By clarifying the material side of the agreement, the notary can detect the criminal intentions of the party to the contract, because there is a real opportunity to distinguish a fraudulent transaction from a deceptive one (Sandrachuk 2007, p. 26).

It should be noted that such interaction is very useful due to the fact that the notary has the opportunity to determine the presence of criminal acts and report it to operatives at the stage of formation of a criminal plan (or the first action in preparation for a criminal offense). The notary performs various standard actions, in particular: obtaining an extract from the register of property rights to real estate or a certificate from the executive committee of the relevant council with the characteristics of the alienated property; obtaining a certificate of no prohibition on alienation; obtaining a notarized consent of the other spouse, if he (she) is a co-owner; obtaining the decision of the tutorship and guardianship agency on the prohibition of a transaction, which violates the rights of persons under guardianship and trusteeship; notarization of the transaction, which takes place under the conditions of providing the notary with title and other necessary documents; State registration of the transaction; State registration of property rights.

Criminals understand that criminal acts on the land market should be continued through the use of notaries, and if they can not involve a notary in a criminal conspiracy, then failure to comply with the form of the land lease contract will result in its non-conclusion, which will prevent further seizure of land, or initiation or legalization of unauthorized construction on unauthorized land (in view of this, the mechanism of their criminal activity includes committing criminal acts at the stage of notarial certificate and State registration of land expropriation transactions (Kniaziev, 2014, p. 25).

However, the registration authorities, as the actors of the interaction, may provide information on the presence of the signs of technical or intellectual forgery (or other signs of a criminal offense) in land titles.

In some cases, it is possible to work with business audit units (Cherniavskyi, 2018) operating in the area of land relations and combating unauthorized construction through internal and external audit (analytical verification, legal verification, economic verification, cross-checking, logical analysis related documents, material and cash flow analysis, random inspection). The auditor should 


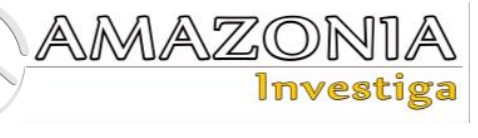

consider two aspects of materiality: quantitative and qualitative. From a qualitative point of view, he (she) must give his (her) professional judgment on the materiality of the audit anomalies. From a quantitative point of view, it is determined whether the individual deviations or their sum exceed the quantitative criteria - the level of materiality. Level of materiality is the most significant accounting error, from which its qualified user is likely to draw incorrect conclusions and make incorrect economic decisions. The concept of materiality is used as the basis for planning an audit in determining the reports that contain errors, evaluating the materials of their own research and deciding on the content of the audit opinion.

In order to improve the interaction between these actors, we consider it appropriate to propose to hold quarterly joint meetings to develop, approve and implement joint activities on land protection and conduct systematic inspections for legality of possession, use and disposal of land for its intended purpose. Follow-up meetings it is advisable to conduct joint raids as part of mobile raid teams established in enterprises belonging to the management of the State Service of Ukraine for Geodesy, Cartography and Cadastre involving the police and the media. It is argued that the problems of detection and investigation of criminal offenses in the area of land relations require the joint efforts of not only law enforcement agencies but also control bodies, including environmental ones (Kuzmychov and Moskvin, 1999, p. 65). Note that the effectiveness of the coordinated activities of the investigator with these agencies is largely determined by the duration of joint efforts.

Such activities may be ad hoc, short-term or permanent. However, a prerequisite for quality cooperation is the study of current land legislation, regulations of ministries, departments, local governments on land protection and their application by investigators. Primary materials on criminal offenses in the area of land relations usually come from control bodies.

Non-procedural or organizational and tactical form of interaction of the investigator with officials of land management organizations, State environmental protection bodies is a common form of interaction. First of all, this applies to obtaining advice from experts on:

1) regulations governing the activities to be inspected;
2) production technologies, organization of control and accounting of production activities;

3) the nature of the documents that reflect the activities of enterprises, institutions, organizations, the order and features of the document flow;

4) special technical, scientific, methodological literature;

5) questions for expert research.

In our opinion, the main non-procedural effective form of cooperation between law enforcement agencies in detecting, investigating and preventing criminal offenses in the area of land relations is interaction with the public and the media. It should be clarified that public participation is not related to the preparation and implementation of procedural actions, but mainly reduced to the following forms:

a) notification of pre-trial investigation bodies of criminal offenses;

b) creation of public formations. There are cases when the public may be involved in the preparation and implementation of procedural actions, in particular: 1) during the investigative experiment; 2) in order to identify sources of information on the circumstances under investigation; 3 ) in order to ensure the protection of crime scene; 4) to perform certain technical procedures necessary for conducting procedural actions, search for and seizure of physical evidence; e) during the implementation of certain organizational measures for prevention.

Different associations of citizens, in particular, the Green Party, domestic and international nongovernmental environmental organizations, and the media, contribute to the fight against criminal offenses in the area of land relations. They cooperate with pre-trial investigation bodies and government agencies on the prevention of environmental offenses in general and in the area of land relations in particular and provide assistance to environmental protection and law enforcement agencies, as well as directly identify such offenses (Oderii 2015, p. 319).

The issue of interaction between the police and the media needs special attention, as the latter are the fastest and most powerful communication channel between law enforcement agencies and the public. Thus, they can be effectively used in matters of: 
a) shaping public opinion on the issues of fighting crime;

b) deepening legal awareness of the population;

c) informing about the activities of law enforcement agencies;

d) assistance in crime prevention.

Sometimes it is the journalists who possess the information for the police, as they more frequent contact with eyewitnesses, who are more willing to give information to media representatives.

The use of the media in investigative activities by employees of pre-trial investigation bodies allows to: a) save time, effort and resources; b) promptly carry out the initiating influence on the population; c) practically no restrictions on territory, population who may be involved in search for places of damage or pollution of land, unauthorized construction, establishing the whereabouts of the offender, etc.

More and more recently, the publication of journalists on the Internet (for example, the programs "Schemes: corruption in detail", "Bihus.Info", etc.) has become the basis for introducing information into the Unified Register of Pre-trial Investigations. On the basis of these materials, the investigation has information about the schemes, persons of interest and often documents indicating transactions with land at the initial stage of investigation.

Thus, the interaction of pre-trial investigation bodies with other law enforcement agencies, State and public institutions, individual citizens and the media is an effective tool for improving the effectiveness of combating criminal offenses in the area of land relations. The effectiveness of the interaction can be achieved only if certain conditions are met. First of all, interacting links, their tasks and scope of should be defined, functional responsibilities should be clearly enshrined; the forms of interaction should be chosen and specific executors should be identified; the objectives should be explained. It is then necessary to ensure the exchange of mutual information, to determine the methods and means of communication (meetings, working discussions of specific situations, telephone contacts, etc.) between the interacting links.

Besides, there should be clear maneuvering of forces and means in accordance with the situation, as well as constant guidance and control over the implementation of agreed joint activities.

\section{Conclusion}

Thus, the interaction of investigators with operational units and other entities in the investigation of criminal offenses in the area of land relations is the system of certain complementary actions, provided by current legislation and agreed in time, place and sequence, aimed at exercising the powers of prosecution in this area using the capabilities of operational units, other entities, including units of the National Police, which are nonoperational, other law enforcement agencies and public authorities and local governments, individual citizens.

The key role among the subjects of interagency cooperation in the investigation of criminal offenses in the area of land relations plays the State Environmental Inspectorate, the State Service of Ukraine for Geodesy, Cartography and Cadastre, the Prosecutor's Office and the National Police, which are authorized to carry out preventive activities, take measures to eliminate and actually investigate them (postfactum). Besides, the activities of such actors include controlling and monitoring activities.

We propose to introduce quarterly joint meetings with regional State administrations, territorial prosecutor's offices, the police, the Security Service of Ukraine, the State Environmental Inspectorate, the State Service of Ukraine for Geodesy, Cartography and Cadastre to develop, approve and implement joint activities on land protection and conduct systematic inspections for verifying the legality of tenure, use and disposal of land for its intended purpose. Follow-up meetings it is advisable to conduct joint raids as part of mobile raid teams established in enterprises belonging to the management of the State Service of Ukraine for Geodesy, Cartography and Cadastre involving the police and media.

The interaction of investigators with operational officers during the investigation of the considered criminal offenses is expressed in: conducting joint activities within permanent or temporary investigative and operational groups; detection of criminal offenses; carrying out covert investigative (search) actions and investigative and search operations related to establishing the facts of criminal activity and missing persons; execution of the investigator's instructions; assisting the investigator in conducting certain investigative (search) actions; mutual exchange of information. 


\section{AMAZONDA \\ 1กveรtกำ}

\section{Bibliographic references}

Batrachenko, O. (2017). Administrative and legal principles of the National Police of Ukraine to ensure public safety and order. (PhD Dissertation). Sumy State University, Ukraine. https://essuir.sumdu.edu.ua/bitstreamdownload/123456789/54848/1/diss_Batrachen ko.pdf

Busel, V. (2001). Large explanatory dictionary of the Ukrainian language. Kyiv-Irpin: Perun.

Cherniavskyi, S. (2018). Interaction of pre-trial investigation bodies with subdivisions of the State Audit Office of Ukraine during the appointment and conduct of audits in criminal proceedings: methodological recommendations. Kyiv: National Academy of Internal Affairs.

Community Relations Service of the U.S. Department of Justice (1993). Principles of Good Policing: Avoiding Violence Between Police and Citizens. https://www.justice.gov/archive/crs/pubs/princi plesofgoodpolicingfinal092003.htm

Feshchenko, L. (2007). Interaction of internal affairs agencies with the state tax service in implementation of law enforcement activity. (PhD Dissertation). Verkhovna Rada Legislation Institute, Ukraine.

Johnson, T. (1972). "Police-Citizen Encounters and the Importance of Role Conceptualization for Police Community Relations". Issues in Criminology, No. 7(1), pp. 103-118. http://www.jstor.org/stable/42909653

Kniaziev, S. (2014). Detection and verification of operational information in combating crimes committed in the housing market. Fight against organized crime and corruption (theory and practice)", No. 1, pp. 22-26.

Kuzmychov, V. and Moskvin, Yu. (1999). Forensic study of criminal activity. Law of Ukraine, No. 5, pp. 65-67.

Law of Ukraine No. 254k/96-VR. Constitution of Ukraine. Official Web site of the Verkhovna Rada of Ukraine, June 28. 1996. Available online. http://zakon2.rada.gov.ua/laws/show/254\%D0\%BA/96-\%D0\%B2\%D1\%80

Law of Ukraine No. 580-VIII. On the National Police. Official Web site of the Verkhovna Rada of Ukraine, July 02 July, 2015 № 580-VIII. Available online. http://zakon5.rada.gov.ua/laws/show/580-19

Oderii, O. (2015). Theory and practice of investigating crimes against the environment: a monograph. Kharkiv: Disa Plus.

Office of the Prosecutor's General of Ukraine (2021). On registered criminal offenses and the results of their pre-trial investigation. https://gp.gov.ua/ua/posts/pro-zareyestrovani- kriminalni-pravoporushennya-ta-rezultati-yihdosudovogo-rozsliduvannya-2

Onisiev, V. (2010). Interaction of law enforcement agencies in the disclosure of legalization (laundering) of proceeds of crime. ( $\mathrm{PhD}$ Dissertation). Kyiv National University of Internal Affairs, Ukraine.

Order of the Ministry of Internal Affairs of Ukraine No. 575. Instruction on the organization of interaction of pre-trial investigation bodies with other bodies and subdivisions of the National Police of Ukraine in the prevention of criminal offenses, their detection and investigation. Official Web site of the Verkhovna Rada of Ukraine, July 07, 2017. Available online. In: http://zakon0.rada.gov.ua/laws/show/z0937-17

Patyk, A. (2010). Cooperation between investigatory and operative-search bodies in detection and investigation of property crimes. (PhD Dissertation). National University of Internal Affairs, Ukraine. http://elar.naiau.kiev.ua/bitstream/123456789/ 1720/1/\%D0\%94\%D0\%98\%D0\%A1\%D0\%95 $\% \mathrm{D} 0 \% \mathrm{~A} 0 \% 20 \% \mathrm{D} 0 \% 9 \mathrm{~F} \% \mathrm{D} 0 \% \mathrm{~B} 0 \% \mathrm{D} 1 \% 82 \%$ D0\%B8\%D0\%BA.pdf

Radburn, M., Savigar-Shaw, L., Stott, C., Tallent, D., \& Kyprianides, A. (2020). How do police officers talk about their encounters with 'the public'? Group interaction, procedural justice and officer constructions of policing identities. Criminology \& Criminal Justice, No. 22(1). DOI: $10.1177 / 1748895820933912$

Research Institute of the Ministry of Internal Affairs of Ukraine (2020). The impact of socioeconomic processes on crime in Ukraine and in the world (according to official materials of the UN, the World Bank, the statistical body of the European Union (Eurostat), the State Statistics Service of Ukraine): an analytical review. Kyiv: DNDIMVS of Ukraine.

Sandrachuk, A. (2007). Fundamentals of detection and investigation of fraud with real estate, which is in private ownership. ( $\mathrm{PhD}$ Dissertation). Odesa National Law University, Ukraine.

http://www.rusnauka.com/31_PRNT_2008/Pra vo/36200.doc.htm

Topchii, V. (2015). The principles of interaction of the investigator and the operational officer of of law enforcement agency in crime detection and investigation. Law and Society, No. 3, Part 2, $\begin{array}{llll}\text { pp. } & 191 & - & 196 .\end{array}$ http://www.pravoisuspilstvo.org.ua/archive/20 15/3_2015/part_2/40.pdf

Yefimenko I. (2014). Interaction of investigative and operational units in the implementation of classified information. (PhD Dissertation). National University of Internal Affairs, Ukraine.

https://mydisser.com/en/avtoref/view/29079.ht $\mathrm{ml}$ 